\title{
Challenges and Solutions: The Experiences of Newly-Qualified Counsellors
}

\author{
Florence Adeoti Yusuf ${ }^{*}$ \\ Ayoade Ejiwale Okanlawon** \\ Imran Moshood Adesile ${ }^{* * *}$
}

\begin{abstract}
The emergence of the increases in the rate of different social vices among the adolescents in high schools calls for re-evaluation and updating of the existing operating counselling services in secondary schools' educational system. The study examined the challenges of the newly qualified school counsellors and the solution proffered. Six research questions were raised to guide the study. It adopted a mixed-method research approach. The results of the findings revealed that the lack of recognition of the role of counsellors in the school system was rated the highest among the challenges experienced by newly-qualified counsellors, nonreferral of students who need to be sent to a counsellor by teachers was rated second. From the findings of the study the awareness campaign on the importance of counselling through various media, the finding "more time should be allotted to practicum for counsellors in training" was the highest-rated as the solution to the challenges experienced by newly-qualified counsellors. The results obtained from the study also revealed that male counsellors might be experiencing different challenges from their female counterparts. The results of the study also show a significant difference in the challenges experienced by newlyqualified counsellors based on school type. The findings revealed that there is a significant difference in the solution provided by newly-qualified counsellors based on gender.The results also show that the solution provided by a counsellor from private schools does not differ from that of their public schools' counterpart. Based on the findings of the study recommendations were made: government should provide public enlightenment programmes to parents, school administrators, teachers, and students through jingles, posters, billboards on the need to embrace counselling in the school system and make use of the facility. National University commission should revise the counsellor training programme and increase the period allocated for practicum for the counsellor in training in order to equip them for the tasks ahead.
\end{abstract}

Key words: challenges, solutions, experiences, newly qualified counsellors

\section{Introduction}

The emergence of the increases in the rate of different social vices among the adolescents in high schools calls for re-evaluation and updating of the existing operating counselling services in secondary schools' educational system. In the recent times, the issue of drug abuse, cultism, gangsterism, violent behaviours, bullying and truancy, classroom indiscipline, examination malpractices, aggression, sexual promiscuity is more pronounced among secondary school students. This trend is having multiple ripple negative effects on the academic development of the students and the society at large. These current behavioural problems

\footnotetext{
* Osun State University, Nigeria

** Osun State University, Nigeria

*** Osun State University, Nigeria

Correspondent Email: olasokoadeoti@yahoo.com, florence.yusuf@uniosun.edu.ng
} 
among adolescents at school are pointing to the fact that students need more functional counselling strategy to shape their behaviours so that they can benefit maximally during the learning process. Wambu \& Fisher (2015) believe that the changing system in the family setting and value orientation of the society is affecting students psychologically and socially. Different pressures from the home front and exposure to different unhealthy conditions in the society are some of the major factors affecting the students' total welfare, academic growth and achievement at school. This is because an individual needs a sound mind to be able to benefit maximally in the learning process. Students are exposed to socio-economic and psychological forces which are making the learning environment unconducive for the teaching and learning process (Mapfumo \& Nkoma, 2013). Given the trends of the social and moral decadence among adolescents in schools, there is a need to overhaul the existing counselling services and strategies at schools.

The increase in maladjusted behaviour coupled with poor academic behaviour is a clear indication that the guidance service provided for this group of students is not effective enough, hence it cannot achieve the desired results. The level of social vices among adolescents at schools had assumed such an alarming rate. The issue of drug abuse, cultism, gangsterism, violent behaviours, bullying, truancy, classroom indiscipline, examination malpractices, aggression, sexual promiscuity, cybercrime, internet fraud, and "yahoo syndrome" are particularly prevalent among secondary school students. All these behaviours among adolescents at secondary schools which are left unattended, so they got the traits carried forward to tertiary education institutions and are escalated to serious behavioural problems among undergraduates, resulting in multiple negative ripple effect on the society. This is a strong pointer to the facts that counselling needs of adolescents at secondary schools should be designed so that their psycho-social needs, emotional needs, academic, and vocational needs are taken care of. It is expected that a dynamic counselling strategy would be able to address the issue of drug abuse, cultism, gangsterism, violent behaviours, bullying and truancy, classroom indiscipline, examination malpractices, aggression, and sexual promiscuity which have become more pronounced among secondary school students in recent times.

Thus, the study sought to find out the challenges of the school counsellors and proffer solutions.

To guide the conduct of the study the following questions were raised:

1. What are the challenges experienced by newly-qualified counsellors?

2. What are the solutions suggested by newly-qualified counsellors?

3. Are there any significant differences in the challenges experienced by newly-qualified counsellors based on gender?

4. Are there any significant differences in the challenges experienced by newly-qualified counsellors based on school type?

5. Are there any significant differences in the solutions provided by newly-qualified counsellors based on gender?

6. Are there any significant differences in the challenges experienced by newly-qualified counsellors based on school type?

\section{Literature Review}

History shows that guidance and counselling have been in existence in Nigeria since 1959, but yet it has not received due recognition, and the desired impact has not been fully felt in the growth and development of adolescents. Makinde (1983) as cited in Idowu (2016) stated that the origin of guidance and counselling in Nigeria dates back to 1959; it started with the Catholic Sisters at St. Theresa's College Ibadan, when they organized a formal career guidance service for their final year students. The guidance and counselling programme enjoyed the support of the government when the Federal Government of Nigeria published 
its 1977 National Policy on Education (NPE) which was revised in 2014. In the document, the government enlists its total commitment and support to the counselling movement by stating that

"given the apparent ignorance of many young people about career prospects, and given personality maladjustment among school children, career officers and counsellors will be appointed in post-primary institutions. Guidance and counselling will also feature in teacher education programmes (NPE, 1981 p.30)."

Counselling having been given a great task to perform in the school system, there are still some fundamental problems which are yet to be addressed for effective implementation. However, counselling as a helping relationship aimed at helping an individual to develop his/her potential maximally. It helps an individual to overcome various challenges of life ranging from an emotional and socio-psychological, to vocational and academic problem. Idowu (2016) cited Okon (1984) who saw guidance as a programme of highly specialized activities implemented by all staff members to help individual to make wise, intelligent and informed choices and decisions. Idowu (2016) also cited Olayinka (1990) who viewed guidance services as the veritable tools that help both the school and the student to achieve the set objectives and aims of education, it also helps students to take full advantages of all facilities the school provides in order to develop their full potentials. Counselling services are provided to take care of the feelings, attitude and emotional stress of an individual that can affect his total development and growth (Tambawal, 2007). Sayai (2019) sees counselling as an interactive relationship between clients and the therapist in a safe, supportive and nonjudgmental environment. Any information shared during the interaction should be kept confidential with some limitations for safety reasons.

To provide guidance services, the guidance counsellor has a great role to perform in the total development of individuals, especially in the school system. Guidance counsellors are expected to provide help to both the parent and the student to understand the educational goals and achieve them (Egbo, 2013). Oviogbolu (2015) sees counselling as various activities aimed at helping individual to resolve his /her challenges. Therefore, it is very clear that guidance is important in a school setting and all members of staff at school are expected to contribute to assisting the students to meet their needs, while the major role of the guidance counsellor is to help the individual student to develop his/her potential maximally.

According to Eyo, Joshua and Esuong (2010), guidance and counselling services for secondary school students are organised to address the socio-physiological, psychological, vocational and academic challenges of an adolescent in secondary school. Despite the important position the guidance services occupy in the educational system, challenges are facing the practice of counselling in schools. Oraegbunam (2008) enumerated some challenges facing counselling in schools ranging from counsellor-client ratio, and non-recognition of counsellor role by the school head to non-inclusion of counselling in the timetable. Another major challenge facing counselling in school is the incompetence of counsellors in resolving pupil's problems (Okere, 2005). While Nwokolo (2006) observed that the combined role of the school counsellor and the lack of his/her autonomy to execute counselling programmes posed challenges to counsellors. This is because most school counsellors are overloaded with teaching subjects and have less time to carry out their professional duty as counsellors.

Erhard and Harel (2005) observed that school counselling services differ based on the following factors: preferences of the school counsellor, school type/ quality, and school authority expectations and value system. In some African countries that are developing countries, Nigeria inclusive, classroom teachers are used as Para-counsellor at schools, they were required to perform the role of a counsellor and as the same time, they were usually loaded with teaching subjects.

Akinade (2009) sees the challenges facing counsellor as a lack of proper training on how to administer and interpret psychological test properly. Nyamwange, Nyakan and Ondima (2012) established that secondary school authorities and students 
generally had a lukewarm attitude towards guidance and counselling services at schools. Nyaga (2013) observed that a parent's lukewarm attitude towards guidance is one of the major factors inhibiting the provided guidance and counselling services in schools. Oye et al. (2012) opined that parents tend to fear of the environment where students will be guided to supply all information that is related to their problems. Okere (2005) observed that most counselling programmes at schools are not properly funded. Nyamwange et al. (2012) also revealed that support given to teachers' counsellors by their school heads is minimal.

Ngumi (2003) observed that the administration of guidance and counselling services in secondary schools is confronted with attitudinal, systemic and cultural problems which are inhibiting provision of effective counselling. In the same vein, Nyamwange et al. (2012) observed that most schools lack facilities needed for implementation of guidance services at school and many schools' authorities find it difficult to support guidance programmes in their schools. This always inhibits the provision of quality guidance services.

Apart from general challenges facing counselling services implementation at school, beginner counsellors have some peculiar challenges. According to Nystul (2003), the beginning counsellors are confronted with the inability to get to the root of the client challenges in a session, not paying attention to physiological issues, struggle to eliminate clients' unhappiness, overambition to get things done properly, anxious to raise his/her level of achievements, exploration tendency, improper management of time during the counselling process, use of wrong phrases, high tendency for helping people, having an irrational belief that he/she must be loved, getting too emotionally attached to the client, making the counselling counsellor-centered, having problems in identifying what is normal or abnormal, not too clear about the concept of self-disclosure, and being uncertain about confidentiality. In the same vein, Corey et al. (2005) identified beginning counsellor challenges: anxiety when meeting the clients the first time, uncertainty about his/her ability as a counsellor to help the client in resolving his/her challenges, hiding his/her true identity, being too careful to avoid mistakes, inability to accept limitations, not knowing how to make the best use of silence in the counselling process, anxious to meet the clients' need, inability to deal with clients who lack commitment, not getting results on time, showing too much concern for the clients, lacking the skill to use the sense of humour in the therapeutic process, overburdening themselves on the outcome of the counselling process, advising the client, not being clear about the role to be played as counsellor and inability to find one's counselling style.

From another study, Pereira and Rekha (2017), found that newly-employed counsellors confronted with professionrelated problems such as incompetency in counselling skills, theories of personality, using various counselling techniques, ethical issues of the profession, anxiety on how to help a client, lack of supervision, poor salary scale and inability to translate theoretical knowledge into practice in the real-life situation. Agrawal (2015) also observed that therapists faced several job-related challenges like poor salaries, availability of job opportunity, licensure problems, and limited awareness about psychological issues.

\section{Methodology}

This study adopted a mixed-method research approach. Qualitative (interpretivism) and quantitative (Positivism) approaches were used in this study. The research questions comprised both the "what" (Positivist) and "why" (interpretivism) questions. The population of this study comprised all counsellors in Osun State, Nigeria.

The study sample comprised 100 counsellors purposively selected from secondary schools in Osun State. The sample was stratified based on gender and school type (public/private).The participants completed the questionnaire entitled "Counselling Challenges and Solutions." The questionnaire consisted of three sections. Section 'A' sought demographic information of the 
respondents, while section ' $\mathrm{B}$ ' was geared towards eliciting information from the respondents on the challenges facing school counsellors. Section $\mathrm{C}$ was geared towards eliciting information from the respondents on the suggested solutions to counselling challenges. Experts in the related field of study assessed the instrument for the study and content validity of the instrument. The split half reliability method was used to measure the internal consistency of the instrument. The reliability coefficient was calculated and the value of 0.84 was obtained. This lends credence to the suitability of the instrument for the study.

A combination of an administered questionnaire and focus group discussions (FGDs) was used for data collection exercise. The questionnaire consisted of a combination of close and open-ended questions. Focus group discussions produce descriptive data about peoples' own written or spoken and observable behaviour. The data were both quantitative and qualitative. The two main procedures were, therefore, applied in the analysis of the data in line with the mixed research approach adopted for the study. Quantitative data were gathered from the close-ended questions. The qualitative data were subjected to content analysis. This involved sorting, categorizing and tallying the data which were mainly additional information to or justification of response given to the close-ended questions, in line with the mixed-model design. For some of the questions, the presentation was then done in narrative form.

\section{Data Analysis}

Table 1: Gender of the respondents

\begin{tabular}{|lcc|}
\hline Variable & Frequency & Percentage \\
Male & 53 & 53.0 \\
Female & 47 & 47.0 \\
Total & $\mathbf{1 0 0}$ & $\mathbf{1 0 0 . 0}$ \\
\hline
\end{tabular}

Table 1 shows that $53 \%$ of the respondents were male while $47 \%$ were female which shows that both sexes are well represented.

Table 2: School type

\begin{tabular}{|lcc|}
\hline School Type & Frequency & Percentage \\
Private school & 50 & 50.0 \\
Public school & 50 & 50.0 \\
Total & $\mathbf{1 0 0}$ & $\mathbf{1 0 0 . 0}$ \\
\hline
\end{tabular}

Table 2 shows that $50 \%$ participants were selected from private schools while other $50 \%$ were selected from public schools.

Table 3 presents the obtained answers to question 1: What are the challenges experienced by newly-qualified counsellors? 
Table 3: Challenges experienced by newly-qualified counsellors

\begin{tabular}{|c|c|c|c|c|c|c|}
\hline S/N & Variables & SA & A & D & SD & Mean \\
\hline 1 & $\begin{array}{l}\text { Training and Application of Practical training was } \\
\text { not enough during studies. }\end{array}$ & $3(3.0)$ & $33(33.0)$ & $46(46.0)$ & $18(18.0)$ & 2.77 \\
\hline 2 & $\begin{array}{l}\text { Exposure to actual counselling settings was not } \\
\text { adequate during studies. }\end{array}$ & $7(7.0)$ & $40(40.0)$ & $29(29.0)$ & $24(24.0)$ & 2.62 \\
\hline 3 & $\begin{array}{l}\text { Awareness and understanding of the importance } \\
\text { of counselling services is low among students. }\end{array}$ & $31(31.0)$ & $54(54.0)$ & $9(9.0)$ & $6(6.0)$ & 3.10 \\
\hline 4 & $\begin{array}{l}\text { There is a lack of recognition of the role of } \\
\text { counsellors in the school system. }\end{array}$ & $37(37.0)$ & $54(54.0)$ & $6(6.0)$ & $3(3.0)$ & 3.42 \\
\hline 5 & $\begin{array}{l}\text { Teachers do not refer students who needs } \\
\text { counselling to counselor. }\end{array}$ & $40(40.0)$ & $47(47.0)$ & $3(3.0)$ & $10(10.0)$ & 3.24 \\
\hline 6 & $\begin{array}{l}\text { Counsellors are overloaded by teaching the } \\
\text { subject. }\end{array}$ & $7(7.0)$ & $40(40.0)$ & $29(29.0)$ & $24(24.0)$ & 2.62 \\
\hline 7 & $\begin{array}{l}\text { Clients' issues lead to emotional exhaustion in the } \\
\text { counsellor. }\end{array}$ & $12(12.0)$ & $30(30.0)$ & $47(47.0)$ & $11(11.0)$ & 2.61 \\
\hline 8 & Students are not ready to seek for counselling. & $35(35.0)$ & $40(40.0)$ & $10(10.0)$ & 15(15.0) & 3.06 \\
\hline 9 & $\begin{array}{l}\text { Clients expect that the counselling is a short-term } \\
\text { process. }\end{array}$ & $27(27.0)$ & $35(35.0)$ & $15(14.0)$ & $23(23.0)$ & 2.83 \\
\hline 10 & $\begin{array}{l}\text { Convincing the parents of the client about the } \\
\text { treatment is a challenge. }\end{array}$ & $30(30.0)$ & $50(50.0)$ & 11(11.0) & $9(9.0)$ & 3.20 \\
\hline 11 & $\begin{array}{l}\text { Clients are reluctant to meet young counsellors } \\
\text { because they think that young counsellors are not } \\
\text { good enough. }\end{array}$ & $14(14.0)$ & $50(50.0)$ & $33(33.0)$ & $3(3.0)$ & 3.11 \\
\hline 12 & $\begin{array}{l}\text { Some teachers are not able to see the usefulness } \\
\text { of counselling for students. }\end{array}$ & 19(19.0) & $35(35.0)$ & $32(32.0)$ & $14(14.0)$ & 2.35 \\
\hline 13 & Many schools do not employ counselors. & 14(14.0) & 49(49.0) & $26(26.0)$ & $11(11.0)$ & 3.01 \\
\hline 14 & $\begin{array}{l}\text { Stakeholders at school do not understand the } \\
\text { importance of counselling. }\end{array}$ & 19(19.0) & $35(35.0)$ & $32(32.0)$ & $14(14.0)$ & 2.35 \\
\hline 15 & Clients are not cooperative. & 14(14.0) & $33(33.0)$ & $46(46.0)$ & $7(7.0)$ & 2.59 \\
\hline 16 & $\begin{array}{l}\text { There is shortage of qualified personnel to handle } \\
\text { counselling services. }\end{array}$ & $35(35.0)$ & $42(42.0)$ & $17(17.0)$ & $6(6.0)$ & 3.06 \\
\hline 17 & Inadequate time is dedicated to counselling & 14(14.0) & $38(38.0)$ & $26(26.0)$ & $22(22.0)$ & 2.44 \\
\hline 18 & $\begin{array}{l}\text { Little support is received from the school } \\
\text { administration. }\end{array}$ & 18(18.0) & $38(38.0)$ & $30(30.0)$ & $14(14.0)$ & 2.64 \\
\hline
\end{tabular}




\begin{tabular}{|c|c|c|c|c|c|c|}
\hline 19 & $\begin{array}{l}\text { There is a lack of parental support for } \\
\text { counselling. }\end{array}$ & $14(14.0)$ & $30(40.0)$ & $29(19.0)$ & $27(27.0)$ & 2.25 \\
\hline 20 & $\begin{array}{l}\text { There is a lack of counselling clinic/laboratory at } \\
\text { schools. }\end{array}$ & $35(35.0)$ & $42(42.0)$ & $17(17.0)$ & $6(6.0)$ & 3.06 \\
\hline 21 & $\begin{array}{l}\text { There is a lack of funding for running counselling } \\
\text { programmes. }\end{array}$ & $35(35.0)$ & $48(48.0)$ & $6(6.0)$ & 11(11.0) & 3.20 \\
\hline 22 & $\begin{array}{l}\text { There is a lack of psychological tests that are } \\
\text { culturally oriented. }\end{array}$ & 19(19.0) & $33(33.0)$ & $22(22.0)$ & $26(26.0)$ & 2.31 \\
\hline 23 & There is a lack of computers for data storage. & 11(11.0) & $28(28.0)$ & $42(42.0)$ & 19(19.0) & 2.31 \\
\hline 24 & Counsellors are not computer literate. & 11(11.0) & 19(19.0) & $27(27.0)$ & $43(43.0)$ & 1.98 \\
\hline 25 & $\begin{array}{l}\text { Internet facilities are not available in the } \\
\text { counsellor's office. }\end{array}$ & $27(27.0)$ & $42(42.0)$ & $17(17.0)$ & $14(14.0)$ & 2.97 \\
\hline 26 & $\begin{array}{l}\text { There is a lack of training to prepare counsellors } \\
\text { for on-line counselling. }\end{array}$ & $21(21.0)$ & $35(35.0)$ & $30(30.0)$ & 14(14.0) & 2.63 \\
\hline 27 & $\begin{array}{l}\text { Relevant equipment is not provided in } \\
\text { Counsellors office. }\end{array}$ & $35(35.0)$ & $48(48.0)$ & $6(6.0)$ & 11(11.0) & 3.20 \\
\hline 28 & There is a lack of furniture for group counselling. & $21(21.0)$ & $35(35.0)$ & $30(30.0)$ & $14(14.0)$ & 2.63 \\
\hline 29 & $\begin{array}{l}\text { There is a lack of uniform mode of operation for } \\
\text { school counsellors. }\end{array}$ & $22(22.0)$ & $24(24.0)$ & $27(27.0)$ & $27(27.0)$ & 2.48 \\
\hline 30 & The counsellor-client ratio is very low. & $27(27.0)$ & $42(42.0)$ & $17(17.0)$ & $14(14.0)$ & 3.12 \\
\hline 31 & $\begin{array}{l}\text { The school head does not give the counsellor a } \\
\text { free hand to operate. }\end{array}$ & $29(29.0)$ & $30(30.0)$ & $22(22.0)$ & 19(19.0) & 2.69 \\
\hline
\end{tabular}

Table 3 above shows that the lack of recognition of the role of counsellors in the school system was the highest-rated challenge experienced by newly-qualified counsellors (3.42), non-referral of students who need to be sent to a counsellor by teachers was rated second (3.24). The respondents rated convincing the parents of the client about the treatment, lack of funding for running counselling programmes and unavailability of equipment in counsellors office as part of the challenges experienced by newlyqualified counsellors (3.20), while counsellors not being computer-literate was rated the lowest challenge facing the newlyqualified counsellors (1.98).

Interviews and focus group discussion on the given issue also revealed diverse opinions concerning the various challenges facing counsellors at school.

One respondent remarked:

"I was given employment because I have English as my teaching subject, my principals sees me as an English teacher and he allows me to provide counselling services only in the aspect of keeping students' record, the little time I am creating to attend to students' needs in the area of counselling is based on my passion for my chosen profession". I am overloaded with teaching, no free day in a week to provide counselling services. My school principal does not see any need for counselling services for students. 
"Ï would have loved to provide counselling services to students to help them resolve various problems facing them as adolescents, but my principal feels I will be competing with him if he allocated a separate office to me as a counsellor and this makes it so difficult for me to organise individual counselling session with students, what I do most time is to create to organise group counselling for students on Fridays for those who are willing. No time allocated for counselling on school timetable, my principal does not see counselling as an important tool for modelling the life of students to benefit maximally in the learning environment."

"My school management makes available necessary facilities for counselling services. I performed solely the role of a counsellor, but I have challenges with some parents who will not want their wards to come for counselling, especially in the area of career counselling and students' placement to class, the parent will want their own interest to be given preference".

"The major problem I have is in the area of interpretation of the psychological test, because some manual of few tests is no longer available".

"As for me, I considered the non-availability of well-furnished counselling office and non-provision of funds are major challenges inhibiting me for functioning effectively as counsellor in my school".

Table 4 views the solutions to challenges experienced by newly-qualifies counsellors (question \#2).

Table 4: Solutions to challenges experienced by newly-qualified counsellors

\begin{tabular}{|c|c|c|c|c|c|c|}
\hline S/N & Variables & SA & A & D & SD & Mean \\
\hline 1 & $\begin{array}{l}\text { Recruitment of more counsellors to reduce the counsellor- } \\
\text { client ratio }\end{array}$ & 21(21.0) & $59(59.0)$ & $14(14.0)$ & $6(6.0)$ & 3.01 \\
\hline 2 & $\begin{array}{l}\text { Awareness campaign on the importance of counselling } \\
\text { through media, jingles, posters, mentioning it on the } \\
\text { assembly ground and during Parents/Teachers Association }\end{array}$ & $26(36.0)$ & $43(43.0)$ & 19(19.0) & $2(2.0)$ & 3.13 \\
\hline 3 & Provision of counselling laboratory/clinic & $24(24.0)$ & $50(50.0)$ & $20(20.0)$ & $6(6.0)$ & 2.92 \\
\hline 4 & $\begin{array}{l}\text { Revision of counselling curriculum, infusion of current issues } \\
\text { that affect all age level and increment of the time allotted } \\
\text { to Practicum }\end{array}$ & $38(38.0)$ & $42(42.0)$ & 13(13.0) & $7(7.0)$ & 3.11 \\
\hline 5 & Training and retraining of counsellor on ICT skills & $46(46.0)$ & $30(30.0)$ & $12(12.0)$ & $12(12.0)$ & 3.10 \\
\hline 6 & $\begin{array}{l}\text { Provision of adequate funds for running of the guidance } \\
\text { services }\end{array}$ & $30(30.0)$ & $27(27.0)$ & $37(37.0)$ & $6(6.0)$ & 2.81 \\
\hline 7 & $\begin{array}{l}\text { Establishment of counselling unit inside and outside the } \\
\text { school setting }\end{array}$ & 16(16.0) & $36(36.0)$ & $41(41.0)$ & $7(7.0)$ & 2.61 \\
\hline 8 & $\begin{array}{l}\text { Advocacy visits to community leaders and other } \\
\text { stakeholders by school counsellors to seek for their } \\
\text { support for guidance services }\end{array}$ & $16(16.0)$ & $43(43.0)$ & $29(29.0)$ & $12(12.0)$ & 2.63 \\
\hline 9 & $\begin{array}{l}\text { Inclusion by the government of counsellors in the next } \\
\text { national policy on education revision committee }\end{array}$ & $35(35.0)$ & $42(42.0)$ & $20(20.0)$ & $3(3.0)$ & 3.09 \\
\hline 10 & Provision of well-equipped for the counsellors & 19(19.0) & $34(34.0)$ & $36(36.0)$ & 11(11.0) & 2.61 \\
\hline
\end{tabular}




\begin{tabular}{|c|c|c|c|c|c|c|}
\hline 11 & $\begin{array}{l}\text { Establishing community-counsellors relationship for proper } \\
\text { integration }\end{array}$ & $12(12.0)$ & $45(45.0)$ & 29(29.0) & $14(14.0)$ & 2.55 \\
\hline 12 & $\begin{array}{l}\text { Sending counsellors by the government to on-line } \\
\text { counselling seminars and workshops }\end{array}$ & $17(17.0)$ & $38(38.0)$ & $39(39.0)$ & $6(6.0)$ & 2.66 \\
\hline 13 & $\begin{array}{l}\text { Improving training of counsellors in training on proper } \\
\text { interpretation of psychological tests }\end{array}$ & $36(36.0)$ & 33(33.0) & $26(26.0)$ & $5(5.0)$ & 3.00 \\
\hline 14 & Encouraging counsellors to seek for current knowledge & $31(31.0)$ & $25(25.0)$ & $26(26.0)$ & 18(18.0) & 2.69 \\
\hline 15 & Supporting counselling services by school administrators & $32(32.0)$ & $35(35.0)$ & $24(24.0)$ & $9(9.0)$ & 2.90 \\
\hline 16 & Creating PET groups at schools by counsellors & $29(29.0)$ & $41(41.0)$ & $20(20.0)$ & 10(10.0) & 2.89 \\
\hline 17 & Allotting more time to practicum for counsellors in training & $37(37.0)$ & $41(41.0)$ & $20(20.0)$ & $2(2.0)$ & 3.13 \\
\hline 18 & $\begin{array}{l}\text { Advocating more actively for establishment of functional } \\
\text { counselling unit in school by professional bodies of } \\
\text { counselling }\end{array}$ & $31(31.0)$ & $27(27.0)$ & $41(41.0)$ & $1(1.0)$ & 3.02 \\
\hline 19 & $\begin{array}{l}\text { Putting supervision strategies in place by professional bodies } \\
\text { of counselling in order to monitor guidance services } \\
\text { provided in schools }\end{array}$ & $27(27.0)$ & $39(39.0)$ & $28(28.0)$ & $6(6.0)$ & 2.87 \\
\hline 20 & $\begin{array}{l}\text { Putting the mentoring strategies in place among } \\
\text { professional bodies }\end{array}$ & $22(22.0)$ & $52(52.0)$ & $22(22.0)$ & $4(4.0)$ & 2.92 \\
\hline
\end{tabular}

Table 4 revealed that awareness campaign on the importance of counselling through media, jingles; and the need to allot more time to practicum for counsellors in training are most highest rated solution to challenges experienced by newly qualified counsellors (3.13), the revision of counselling curriculum and infusion of current issues that affect all age levels are rated as the second solution (3.11), while training and retraining counsellors in computer literacy are rated as the third solution by the respondents (3.10). Establishing community-counsellors relationship for proper integration is rated as the lowest solution to challenges experienced by newly-qualified counsellors (2.55).

Questions 3 and 4 (Are there any significant differences in the challenges experienced by newly-qualified counsellors based on gender and school type) are analyzed in Tables 5 and 6 through t-test.

Table 5: Summary of t-test computed for the significant difference in the challenges experienced by newly-qualified counsellors based on gender

\begin{tabular}{lllllllll}
\hline & Gender & N & X & SD & DF & T & Sig. & Remark \\
\hline $\begin{array}{l}\text { Challenges } \\
\text { experienced }\end{array}$ & Male & 53 & 3.569 & 1.504 & 99 & 5.744 & 0.030 & Significant \\
& Female & 47 & 3.612 & 1.427 & & & & \\
\hline
\end{tabular}

*Denote significance at $\mathrm{p}<0.05$

Table 5 shows the result of the challenges experienced by newly-qualified counsellors based on gender. The mean and standard deviation of male counsellors $(M=3.569, S D=1.504)$ and female counsellors $(M=3.612, S D=1.427)$ with $(t=5.744, d f=99$, $p<0.05)$. This shows that there is a significant difference in the challenges experienced by newly-qualified counsellors based on 
gender since the significant level value of 0.030 is less than 0.05 alpha level. The result obtained revealed that male counsellors might be experiencing different challenges from their female counterpart. Therefore, the null hypothesis was rejected.

Table 6: Summary of t-test computed for the significant difference in the challenges experienced by newly-qualified counsellors based on school type

\begin{tabular}{lllllllll}
\hline & School type & N & X & SD & DF & T & Sig. & Remark \\
\hline $\begin{array}{l}\text { Challenges } \\
\text { experienced }\end{array}$ & Private school & 50 & 3.459 & 1.438 & 99 & 1.88 & 0.613 & Not Significant \\
& Public school & 50 & 3.824 & 1.614 & & & & \\
\hline
\end{tabular}

*Denote significance at $p>0.05$

Table 6 above shows the result of the significant difference in the challenges experienced by newly-qualified counsellors based on school type. The mean and standard deviation of private school counsellors $(M=3.459, S D=1.438)$ and public-school counsellors $(M=3.824, S D=1.614)$ with $(t=1.88, d f=99, p>0.05)$. The result showed no significant difference at 0.05 level of significance with $p$ value of 0.613 . This implied that the challenges experienced by newly-qualified counsellors from private school is not different from that of their counterpart in public schools. Hence, the null hypothesis is accepted.

Answers to questions 5 and 6 (Are there any significant differences in the solutions provided by newly-qualified counsellors based on gender and school type) are analyzed in Tables 7 and 8 through t-test.

Table 7: Summary of t-test analysis computed for the significant difference in the solution provided by newly-qualified counsellors based on gender

\begin{tabular}{lllllllll}
\hline & Gender & N & X & SD & DF & T & Sig. & Remark \\
\hline Solution provided & Male & 53 & 3.351 & 1.921 & 99 & 4.091 & 0.022 & Significant \\
& Female & 47 & 3.421 & 1.252 & & & & \\
\hline
\end{tabular}

*Denote significance at $p<0.05$

As shown in Table 7 above, an independent $\mathrm{t}$-test was conducted to compare the difference in the solution provided by newlyqualified counsellors based on gender. There was a significant difference between the scores for males $(M=3.351, S D=1.921)$ and females $[M=3.421, S D=1.252) ; t(4.091)=0.022, p<0.05]$. The magnitude of the differences in the means was statistically significant with $\mathrm{P}<0.05$. With the above result, we accept hypothesis seven and conclude that there is a significant difference in the solution provided by newly qualified counsellors based on gender.

Table 8: Summary of t-test analysis on the significant difference in the solution provided by newly-qualified counsellors based on school type

\begin{tabular}{llllllll}
\hline School type & N & $\mathbf{X}$ & SD & DF & T & Sig. & Remark \\
\hline Private school & 50 & 3.011 & 1.292 & 99 & $2.813^{*}$ & 0.33 & Not Significant
\end{tabular}




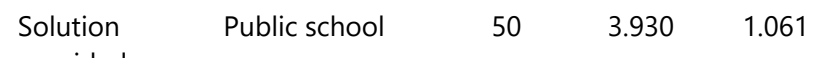
provided

*Denote significance at $p>0.05$

Table 8 shows the result of significant difference in the solution provided by newly-qualified counsellors based on school type. The mean and standard deviation of counsellors from private schools $(M=3.011, S D=1.292)$ and counsellors from public school $(M=3.930, S D=1.061)$ with $(t=2.813, d f=99, p>0.05)$ shows that there is no significant difference in the solution provided by newly- qualified counsellors based on school type. It shows that solution provided by counsellor from private schools does not differ from their public schools. Hence, the null hypothesis is accepted.

\section{Discussion}

The findings of the study revealed that the lack of recognition of the role of counsellors in the school system is the highest-rated challenge experienced by newly-qualified counsellors (3.42), non-referral of student who needs to be sent to the counsellor by teachers is rated as the second challenge (3.24). The respondents rated convincing the parents of the client about the treatment, lack of funding for running counselling programmes and unavailability of equipment in counsellors office as the third challenge experienced by newly-qualified counsellors (3.20). The result of the study is in line with the observation of Oraegbunam (2008) who enumerated some challenges facing counselling in schools as the counsellor/client ratio, non-recognition of counsellor role by the school head, and non-inclusion of counselling in the timetable.

The findings of the study also supported the idea of Nyamwange, Nyakan and Ondimu (2012) that secondary school authorities and students generally had a lukewarm attitude towards guidance and counselling services at schools. The findings of the current study are in line with the finding of Nyamwange et al. (2012) that most schools lack facilities needed for implementation of guidance services at school and many schools authorities find it difficult to support guidance programmes in their schools, which always inhibits the provision of quality guidance services. The results of the finding is also in line with the findings of Anagbogu, Nwokolo, Anyamene, Anyachebelu and Umezulike (2013) who emphasize the lack of a counselling laboratories, storage facilities for data, internet facilities, equipment such as audio recorder, etc. They mention the inadequate number of counsellor, not having a counseling period in the school time table among the major problems faced by school counsellors.

The findings of the study also revealed that one of the major problems of a newly- qualified counsellor is in the area of interpretation of psychological tests because some manuals are no longer available. The findings of the study supported the observation of Akinade (2009) that counsellors face such challenges as the lack of proper training on how to administer and the inability to interpret psychological test results properly.

The findings presented in Table 4 revealed that awareness campaign on the importance of counselling through media, jingle and more time should be allotted to practicum for counsellors in training is the highest-rated solution to the challenges experienced by newly- qualified counsellors (3.13), revision of counselling curriculum and infusion of current issues that affect all age levels are rated as the second solution to the challenges experienced by newly-qualified counsellors (3.11), while training and retraining counsellors in computer literacy was rated as the third solution by the respondents (3.10). The findings of the 
current study is in line with the findings of Arowolo (2013) who found non-exposure of counselors to in-service training as one of the top problems affecting counselors' functionality .

Table 5 shows that there is a significant gender-based difference in the challenges experienced by newly-qualified counsellors, since the significant level value of 0.030 is less than 0.05 alpha level. The finding may be an indication that male counsellors in Nigeria cope with challenges better than female ones. The findings of the current study supported the findings of Artkoski and Saarnio (2013) that female therapists were more positive than male ones in their attitude towards therapist's client preferences. The results of this finding also corroborate the findings of Kamunyu et al. (2019) that male and female students preferred seeking counselling from same-gendered counsellor, especially on the personal-related issues. Most of the researchers' findings showed the indication that gender can affect the functionality of male both as a therapist or a client.

The findings in Table 6 show significant differences in the challenges experienced by newly-qualified counsellors based on school type. This implied that the challenges experienced by newly-qualified counsellors from a private school are not different from that of their counterpart in public schools. The findings of the current study supported the finding of Erhard and Harel (2005) that school counselling services differ based on the following factors: preference of the school counsellor, school type/quality, and school authority expectations and value system

As shown in Table 7, there is a significant difference in the solution provided by newly-qualified counsellors based on gender. This may be a result of differences in the thought pattern of men and women when it comes to finding solution to problems. Clement et al. (2015) revealed that men find it difficult to disclose their challenges. The results of the findings also supported the observation of Kingerlee et al. (2014) that women seek for psychological interventions more often than men.

Table 8 shows the result of the significant difference in the solution provided by newly-qualified counsellors based on school type. This shows that there is no significant difference in the solution provided by newly-qualified counsellors based on school type. It is shown in the current research that the solution provided by a counsellor from private schools does not differ from their public schools' counterpart. The finding may be due to the fact that all newly-qualified counsellors are being confronted by similar challenges irrespective of their school type. The results of the findings supported the observation of Proti (2016) that the feelings of incompetence are characteristics in the development of newly qualified counselors' professional identity. The findings of the current study are also in line with the findings of D'Souza, Egan, \& Rees, (2011) that the tendency for therapists to gain more experience, to improve their skills with perfectionism can be stressful for them.

\section{Conclusion and Recommendations}

The role of counselling services in the positive development of an individual, coupled with its role in helping students in making informed career choice and decisions, helping the students to benefit maximally in the learning process and to develop fully their potentials cannot be underestimated. It has been observed that the lack of recognition of the role of counsellors in the school system is the major challenge experienced by newly-qualified counsellors. It is, therefore, recommended that public enlightenment be provided to all stakeholders in education on the importance of counselling for students.

The following recommendations were made:

- Government should provide public enlightenment programmes to parents, school administrators, teachers, students through jingles, posters, billboards on the need to embrace counselling in the school system and make use of the facility. 
- The Ministry of Education should enforce the establishment of guidance and counselling unit at schools.

- School counsellors should be periodically attending conferences, seminars, workshops in order to update their knowledge on current issues concerning counselling services and new challenges among adolescents at school.

- The National University Commission should revise the counsellor training programme and increase the period allotted to practicum for counsellors in training to be well equipped for the tasks ahead.

- The Ministry of Education should revise the counselling curriculum and infuse current issues that affect all age levels.

- Professional bodies of counselling should make intensive efforts to ensure that counselling services provide full recognition by school administrators.

- Government should improve the welfare in the school environment by providing adequate infrastructural facilities and counselling laboratories that will enhance effective counselling services at schools. 


\section{References}

Akinade, E.A. (2009). Psychological testing in counselling. CASSON Journal (Special Edition), 25(1): 86-95.

Anagbogu, M. A., Nwokolo, C. N., Anyamene, A. N., Anyachebelu, F. E. \& Umezulike R. Q. (2013). Professional challenges to counselling practice in primary schools in Anambra State, Nigeria: The way forward. International Journal of Psychology and Counselling. 5(5), 97-103.

Arowolo, D.O. (2013). Counsellors' perception of problems facing guidance and counselling services in Nigerian schools. Journal of Education and Practice 4(24), 115-118

Artkoski, T. \& Saarnio, P. (2013). Therapist's gender and gender roles: Impact on attitudes toward clients in substance abuse treatment. Journal of Addiction, 12-14 article 591521. DOI: 10.1155/2013/591521

Clement, S., Schauman, O., Graham, T., Maggioni, F., Evans-Lacko, S., Bezborodovs, N. Thornicroft, G. (2015). What is the impact of mental health-related stigma on help-seeking? A systematic review of quantitative and qualitative studies. Psychological Medicine, 45 (01), 11-27.

Corey, G., Corey, M.S. \& Cathanan, P. (2003). Issues and Ethics in the Helping Profession (6th Ed.) Pacific Grove. CA: Brooks and Cole.

Egbo, A.C. (2013). The role of guidance and counselling in effective teaching and learning in schools: The Nigerian perspective. The European Conference on Education. Retrieved from http://iafor.org/archives/offprints/ece2013offprints/ECE2013_0392.pdf.

Erhard, R. \& Harel, Y. (2005). Role behaviour profiles of Israeli school counsellor. International Journal for the Advancement of Counselling 27, 87-100.

Eyo, M.B., Joshua, A.M. \& Esuong, A.E. (2010). Attitude of secondary school students towards guidance and counselling services in Cross River State. Edo Journal of Counselling, 3(1), 87-99.

Idowu, A.I. (Ed.). (2016). Guidance and Counselling in Education. Ilorin, Nigeria: University of Ilorin Press.

Kamunyu, R., Ndungo, C., \& Wango, G. (2019) Influence of presenting problems in choice of counsellor gender. Journal of Humanities and Social Science, 24(8), 71-77.

Kingerlee, R., Precious, D., Sullivan, L., \& Barry, J. A. (2014). Engaging with the emotional lives of men: Designing and promoting male-specific services and interventions. The Psychologist, 24, 418-421.

Mapfumo, J. \& Nkoma, E. (2013). The state of guidance and counselling programmes in high schools in Manicaland, Zimbabwe. International Journal of Scientific Research in Education, 6(2), 100-116.

Ngumi, O.N. (2003). Assessment of the level of training and resource needs of secondary school guidance counsellors in Nakuru municipality, Kenya. Unpublished M.ED Thesis. Njoro, Kenia: Egerton University.

Nwokolo, C.N. (200) Appraisal of the implementation of guidance and counseling service at the post-primary level. UNIZIK Orient Journal of Education, 1, 235-242.

Nyaga, J.I. (2013) Impact of Head Teacher Support in the Implementation of Guidance and Counseling in Secondary Schools in Mombasa District, Kenya. Retrieved from https://www.semanticscholar.org/paper/lmpact-of- 
headteachers\%E2\%80\%99-support-on-the-of-guidance-

Nyaga/b7b9820e59e4fa699e8bfa55f8b499947095ec7f\#references

Nyamwange, C.B., Nyakan, P.O \& .Ondima, P.C. (2012). Assessment of challenges facing secondary school guidance and counselling teachers in Nyamira district, Kenya. Journal of Education and Practice, 3(16), 41-47.

Nystul, M.S. (2003). Introduction to Counseling. An Art and Science Perspective (2nd Ed). New York: Allyn and Bacon.

Oviogbodu, C.O. (2015). Perceived impact of guidance and counseling in the development of Niger Delta Region. Niger Delta University conference Education and Sustainable Development in the Niger Delta Region of Nigeria. The University Entrepreneur Center new site Niger Delta University, Abuja, Nigeria. 9th - 12th August.

Okere, A. (2005). The effective school counsellors: Perception of students, teachers and counsellors. Journal of Education Foundations, 1, 147-152

Oraegbunam, N.M. (2008). Guidance and Counselling: A missing link in the pre-primary and primary education in Anambra State. International Journal of Educational Resources Development, 3(1), 19-27.

Oye, N.D., Obi, M.C, Mohd, T.N, \& Bernice, G.A. (2012). Guidance and counselling in Nigerian secondary schools: The role of ICT. Modern Education and Computer Science, 8, 26-33.

Pereira, M. \& Rekha, S. (2017) Problems, difficulties and challenges faced by counsellors. International Journal of Indian Psychology, 4(3), 65-72.

Proti, L.E. (2016), Challenges encountered by psychotherapists at the beginning of their practice. Romanian Journal of Cognitive Behavioral Therapy and Hypnosis 3, (1), 5-10.

Sayal, M. (2019). What is counselling? Retrieved March 16, 2021 from https://www.shiftcollab.com/blog/what-is-counselling

Tambawal, M.U. (2007) Counselling for effective management of human resources. CASSON Conference at Ota, Ogun State. August 14-17. Retrieved from http://oer.udusok.edu.ng 